\title{
Flood inundation mapping for the Gwadar city
}

\author{
Karamat Hussain Barlaas ${ }^{1}$, Habib ur Rehman ${ }^{2}$, Mohsin Siddique $^{3 *}$, Abdul Sattar Shakir ${ }^{2}$, \\ and Muhammad Naeem Akhtar ${ }^{2}$ \\ ${ }^{1}$ Public Works Department, AJ\&K Muzaffarabad, Pakistan \\ ${ }^{2}$ Department of Civil Engineering, UET, Lahore, Pakistan \\ ${ }^{3}$ Department of Civil and Environmental Engineering, University of Sharjah, UAE
}

\begin{abstract}
Floods wreak havoc with human society, infrastructure and the environment. Accuracy and reliability of the forecasts concerning the resultant inundation depths and extents of these floods are primarily dependent upon the employed hydrologic modeling approach. In the present study, a more precise distributed hydrological modeling approach has been exploited with grid-based spatial discretization for the simulation of flood inundation in Akara river watershed which contains a proposed metropolitan-level developed coastal city of Gwadar in the 'Balochistan' province of Pakistan. Institute of Industrial Sciences Distributed Hydrological Model, a physically based distributed hydrological model, has been employed. This model, through fully implicit finite difference schemes, utilizes diffusive wave approximations of 1D and 2D Saint Venant's governing equations for the river and over-land flow components, respectively. While the model is calibrated against the cyclonic flood event of June 2007, to earmark the potential hazardous areas inside as well as outside the Master Plan boundary the flood inundation simulation for the worst precipitation events of 50 and 100 years return periods are performed. The simulated flood inundation depths at various known locations showed good agreement with the observed ones. Moreover, the simulations depict that the simulated flood inundation depths at the same locations increase by 1.07 to 1.87 times and 1.21 to 1.89 times respectively due to 50 and 100 years return period rainfalls.
\end{abstract}

\section{Introduction}

Proposed mega scale development in the Gwadar City would increase the land use in Akara river watershed and consequently the area would become more vulnerable to flood inundations in the wake of any likely worst event of precipitation. Relatively more precise appraisal of this inundation is, therefore, inevitable. The effectiveness of a hydrologic forecast about timings, depths and extents of the inundation is indisputably highly dependent upon the degree of precision and accuracy of the techniques involved in the quantification of the surface and river flows in response to a precipitation event.

\footnotetext{
* Corresponding author: msiddique@sharjaha.ac.ae
} 
In the abovementioned context, the application of remote sensing (RS) and geographic information system (GIS) techniques have become popular in Pakistan to study and predict the various aspects of flooding in the rivers. Many researchers have been applying these RS and GIS techniques either standalone or coupled with additional rainfall-runoff models for the past many years. For example, Haq et al. applied RS and GIS to study the flood monitoring and damage assessment in Sindh province of Pakistan [1] ; Hussain et al. mapped Pakistan 2010 flood using RS data [2]; Khan et al. used RS techniques to conclude that RS data integrated from multispectral and microwave sensors could be used to supplement stream gauges in sparsely gauged large basins to monitor and detect floods [3] and Shakeel et al. performed pre and post flood analysis of 2014 flood along the river Chenab using RS and GIS technique [4].

The present study is, therefore, aimed to use GIS techniques in a more precise physically based distributed hydrological model named as Institute of Industrial Sciences Distributed Hydrological Model (IISDHM) to perform flood inundation in Akara river watershed and to prepare flood inundation maps for the Gwadar city in the event of 50 and 100 years return period rainfalls.

\subsection{Location, extent, demography and climate of the Gwadar city}

Gwadar district lies in the extreme south of 'Balochistan' province of Pakistan. On the north, it is adjoined by other two 'Balochistan' districts; Turbat and Awaran. On its west, it bounds Pakistan with Iran while on the south it constitutes more than $600 \mathrm{~km}$ long coast of Pakistan with Arabian Sea. In the south, its coast embraces the Gulf of Oman, across which lies the oil rich Middle East. On its eastern side lies the Lasbela, a bounding district of Balochistan with Sindh province. Geographically the Gwadar district is located in-between longitude $60^{\circ} \mathrm{E}-66^{\circ} \mathrm{E} \&$ latitude $25^{\circ} \mathrm{N}-27^{\circ} \mathrm{N}$ (Figure 1). The old town of Gwadar lies on the Arabian Sea coast about $48 \mathrm{~km}$ to the east of the Gwadar bay. Based on the census of 1981, population of the Gwadar town area is about 43,250 persons with density of 7.4 persons per $\mathrm{km}^{2}$ [5].The newly proposed Gwadar city by Gwadar Development Authority stretches across the newly named bays as East Padi Zar (East Bay) and West Padi Zar (West bay). 


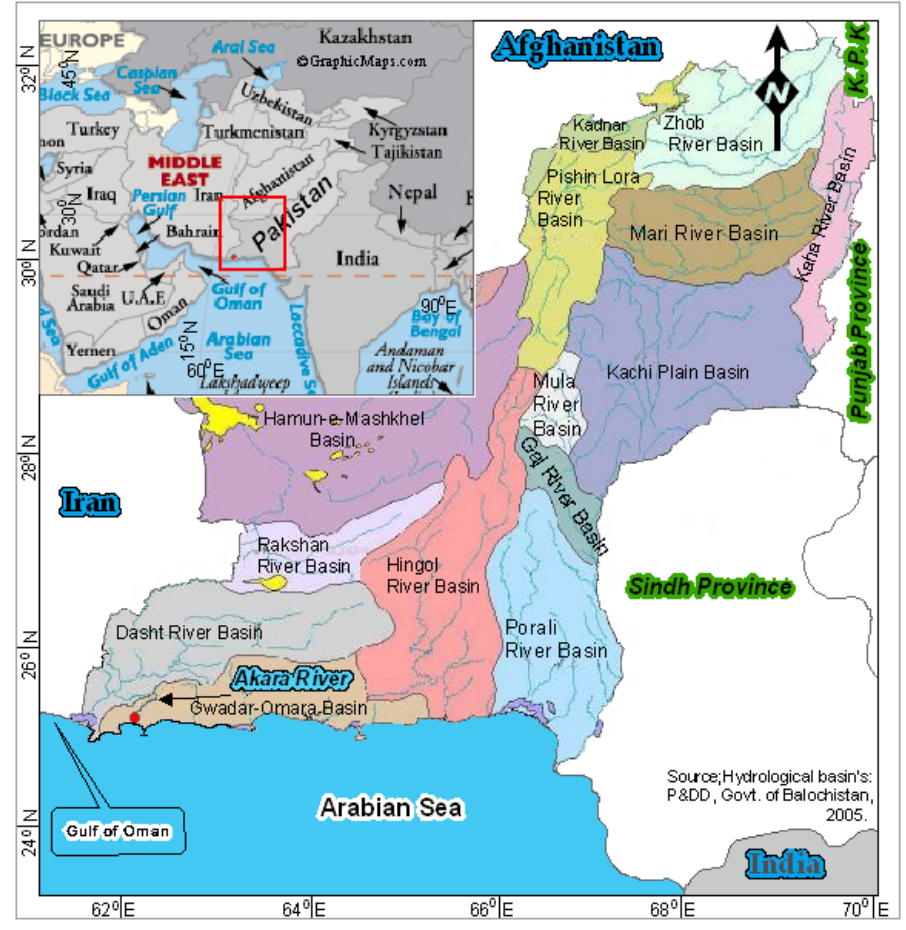

Fig. 1. Geographic location and hydrological context of Gwadar city.

The climate of Gwadar may be classified as arid with warm summer and mild winter. The annual rainfall varies from 75 to $100 \mathrm{~mm}$ [6]. The winter rain decreases with the increase in longitude. Rainfall is highly variable in intensity and duration. It is also highly unpredictable, because it occurs inconsistently and occasionally implying that there is no fixed cycle of the rainfall. Actually, downpours are mostly due to local atmospheric disturbances in the sea [7]. Hydrologically the Gwadar city is located in the 'Akara' river basin. It is one of the many sub basins of the major Gwadar-Omara basin of the Balochistan as shown in Figure 1.

\section{Institute of industrial sciences distributed hydrological model (IISDHM)}

IISDHM is a physically based distributed hydrological model comprising of major processes of hydrological cycle, i.e., interception, evapo-transpiration, river flow, surface flow, and unsaturated and saturated zone flows. A schematic demonstrating of all of the components of IISDHM model is shown in Figure 2. IISDHM is capable of modeling both the overland and sub-surface flow ([8], [9], [10], [11], [12] \& [13]). For the subsurface flow, it makes use of 3D Richards Equations. For modeling the two dimensional flow, the model operates on square grid spatial resolution. With the resolution fineness, the model has certain processing constraints owing to its data structure.

For the present study, the surface and river components of the IISDHM are used for the flood inundation simulation. The model makes use of implicit finite difference scheme for solving its diffusive wave form governing equations. In this model, one-dimensional 
Saint-Venant Equations $(1 \&$ \& $)$ simulate the river flow while the two-dimensional SaintVenant Equations $(3,4, \& 5)$, simulate the surface flow routing.

The One-dimensional Saint-Venant Equations for river flow can be written as:

$$
\begin{gathered}
\frac{\partial Q}{\partial x}+\frac{\partial A}{\partial t}=q \\
\frac{\partial Q}{\partial t}+\frac{\partial}{\partial x}\left[\frac{Q^{2}}{A}\right]=-g\left(\frac{\partial Z}{\partial x}+\underset{f}{S}\right)
\end{gathered}
$$

Where, $Q$ is the discharge through the cross-sectional area $A, x$ is the distance along longitudinal direction of flow, $t$ is the time, $q$ is the lateral inflow or out flow distributed along the $\mathrm{x}$-axis of the waterway, $Z$ is the water surface elevation with respect to datum, $g$ is gravitational acceleration constant and $S_{f}$ is frictional slope.

The 2D Saint-Venant's governing equations for the overland flow used in present IISDHM can be written as:

$$
\begin{gathered}
\frac{\partial u h}{\partial x}+\frac{\partial v h}{\partial y}+\frac{\partial h}{\partial t}=q \\
u \frac{\partial u}{\partial x}+v \frac{\partial u}{\partial y}+\frac{\partial u}{\partial t}=-g\left(\frac{\partial z}{\partial x}+\underset{f x}{S}\right) \\
u \frac{\partial v}{\partial x}+v \frac{\partial v}{\partial y}+\frac{\partial v}{\partial t}=-g\left(\frac{\partial z}{\partial x}+\underset{f y}{S}\right)
\end{gathered}
$$

Where, $u \& v$ are velocities of flow in $\mathrm{x}$ and y-directions and $S_{f x}$ and $S_{f y}$ are friction slopes in $x$ and $y$-directions, respectively.

For river and surface flow routing, diffusive approximations of 1D and 2D SaintVenant's equations are used based on method of diffusion analogy [14]. It is done by solving implicitly the respective equations through finite difference schemes with a uniform network of square grids. The exchange of flow between the channel network and floodplains is simulated using the floodplain compartment concept. The floodplain compartments are surface grids along the river channel network, which are considered as boundary condition in overland flow routing. Flow transfer between flood plain compartments and river is assumed to occur along the respective $\Delta x$ reaches adjoining the river and floodplain compartments. Further, this flow is assumed as flow over broad crested weir with submergence correction.

Now, the flow can be either away from the river or into the river, depending upon the relative water surface elevations of the river grid and the flood plain compartment. The river elevations are computed using 1D diffusive wave model equations for channel network and the flood plain elevations are computed by 2D diffusive wave model equations for overland flow. The exchange of flow between floodplain compartment and river reach in each time step $\Delta t$ is computed by a simple storage routing relation:

$$
V_{l}^{t+1}=V_{l}^{t}+\left(I^{t+1}-O\right) \Delta t
$$

Where, $V_{l}$ is the volume of water in the flood plain compartment at time $t+1$ or $t$ depending on the water elevation, $I$ is the inflow from the river grids to adjacent floodplain compartments, and $O$ is the outflow from the floodplain compartments to adjacent river grids [11]. 


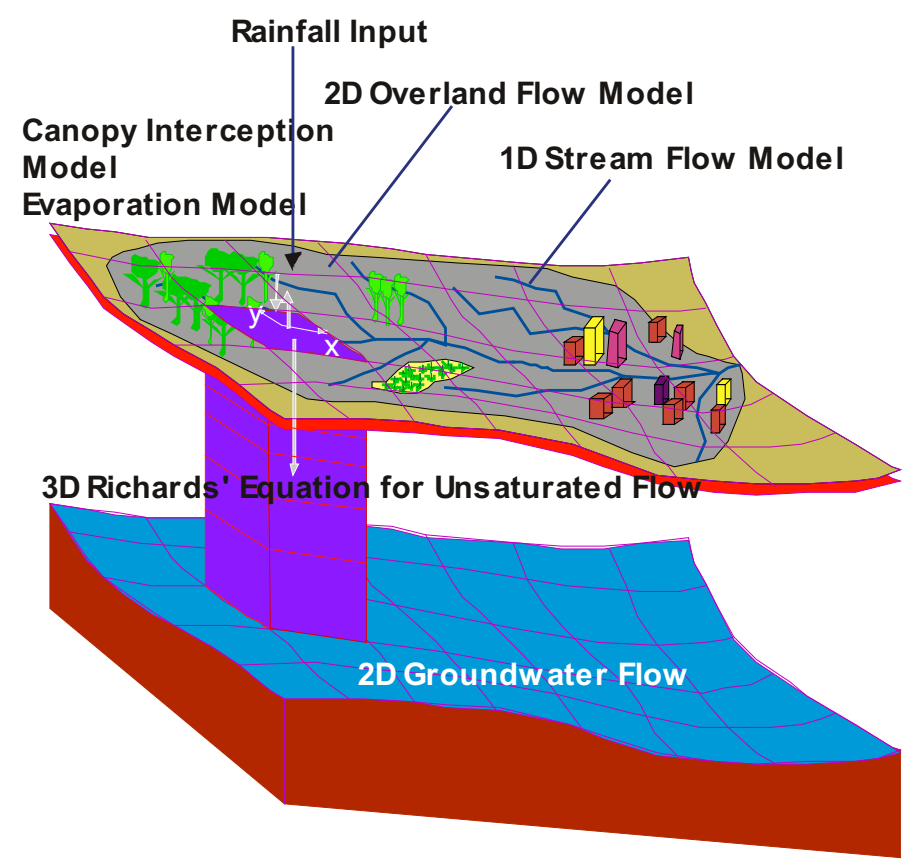

Fig. 2. Schematic representation of IISDHM.

\section{Methodology}

Methodology in computational modeling is most of the times subservient to the type of the input file formats of the employed models. In the present work, IISDHM dictates its two types of data sets (i.e., spatial and temporal) whose collections from various sources and subsequent formatting in line with the input requirement of the model instantiate the methodology of the present research. Transformation of the output in the graphical format is another feature of the methodology. Schematic diagram of the flood inundation mapping through hydrological modeling, shown in Figure 3, is the best illustrative of the methodology. Spatial and temporal data sets formatted in appropriate form serve as input to model. IISDHM after execution of its respective modules produces output in ASCII format files. These files are, further, processed through ARCGIS version 9.2 in grid format. 


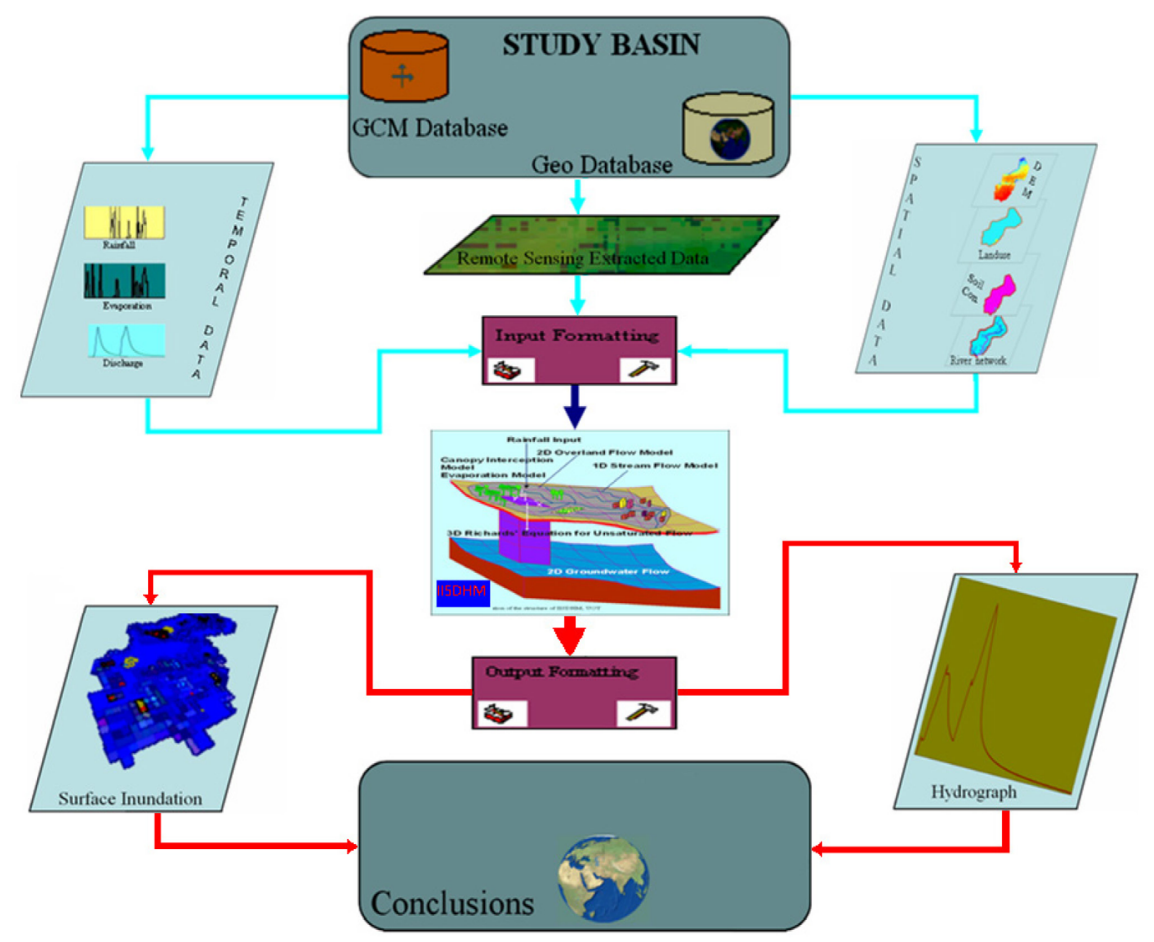

Fig. 3. Schematics of flood inundation mapping.

\section{Data collection and model settings for analysis}

\subsection{Spatial data}

Digital Elevation Model (DEM) provides the most important data set that governs the overall flow pattern in the catchment. Resolution of the DEM plays a very crucial role in determining the accuracy and robustness of the results of a model. However, different computational and data access constraints permitted the use of $1 \mathrm{~km}$ grid resolution. DEM from GTOPO Official website of U.S Geological Survey (USGS) was accessed for downloading DEM of concerned basin as shown in Figure 4(i). Land use map of the study area was downloaded from the Food and Agriculture Organization (FAO) official website. Its grid resolution was $919 \mathrm{~m}$ and the grid size was, therefore, rescaled to $1 \mathrm{~km}$ according to the requirement of DEM resolution. Watershed extracted from DEM and its various phases of processing are shown in Figure 4.

Owing to the scope of the present study, the arbitrary values of parameters corresponding to sub-surface flow were utilized during the run of the model. Moreover, Gwadar city's proposed Master Plan was obtained from the Gwadar Development Authority (shown in Figure 4(ii)). It required many adjustments regarding its resolution and spatial reference, which were achieved by intensive geo- processing in ARCGIS. Land use map shown in Figure 4(iii) was also tailored accordingly. The study specific clipped tile was processed for Akara river raster delineation as shown in Figure 4(iv). It was then 
overlaid by the city Master Plan shown in Figure 4(v). Projected 3D view of the fit-in Master Plan is shown in Figure 5.

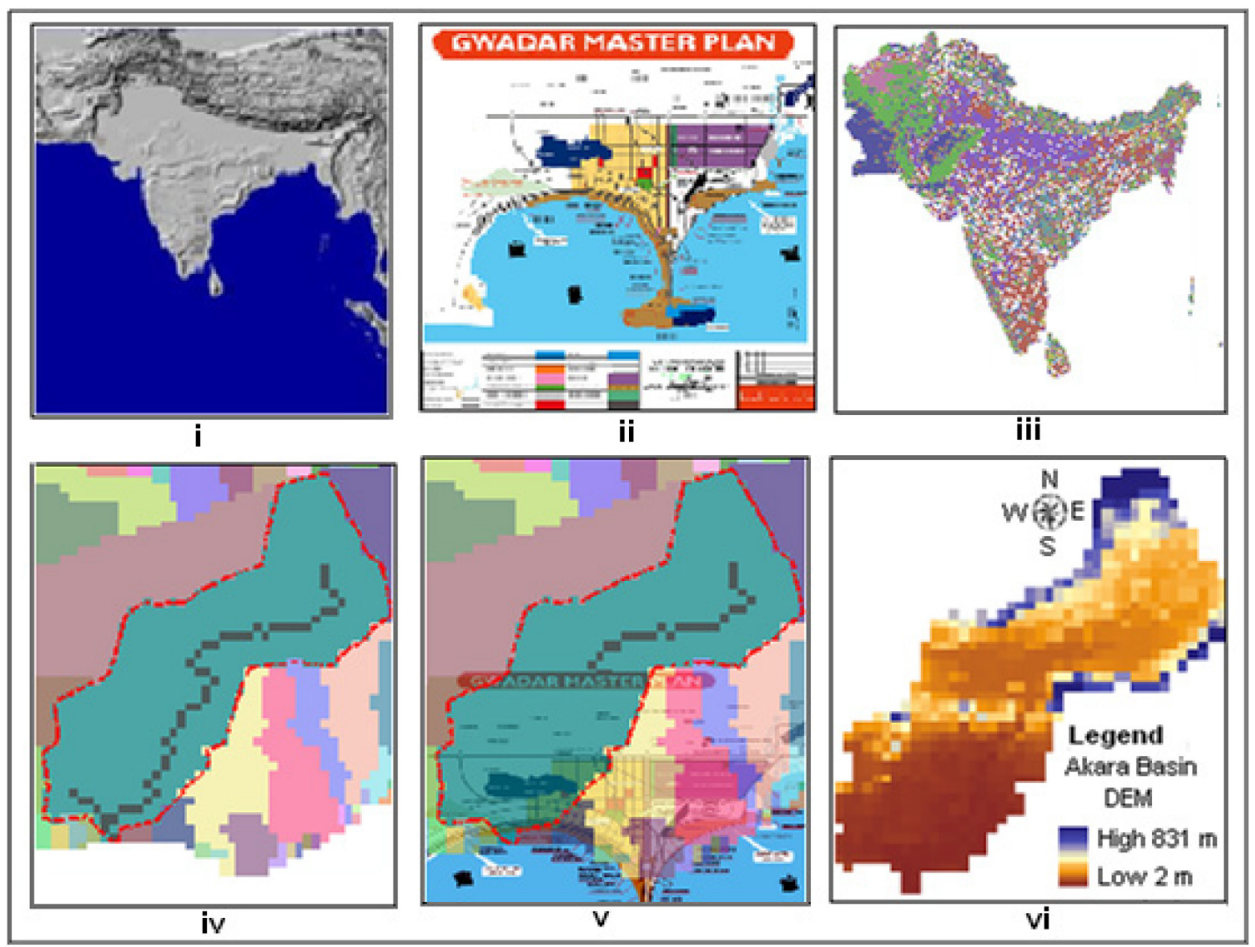

Fig. 4. i) Downloaded DEM, ii) Gwadar Master Plan, iii) Land use map of South Asia, iv) Master Plan specific clipped and processed watersheds, v) watersheds in clipped tile overlaid by the city Master Plan, vi) Akara river basin DEM (processed). 


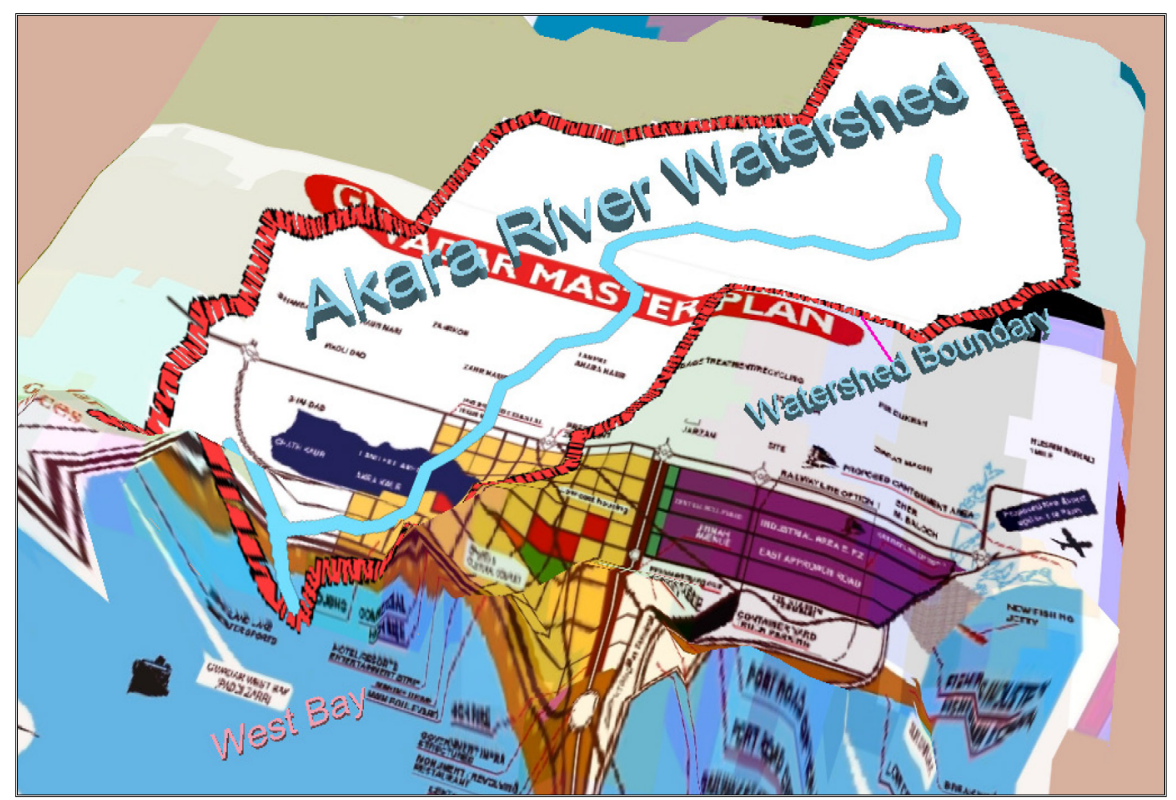

Fig. 5. 3D view of the fit-in Master Plan

\subsection{Temporal data}

Temporal data comprises of precipitation, evaporation and stream flow data sets. Stream gauging data corresponding to precipitation data of duration 2002-2007 could not be available. Instead the maximum surface inundation mark that resulted from the past cyclonic precipitation of June 2007 was utilized. Precipitation data for the duration 20022007 regarding the Gwadar city is tabulated below in Table 1. Precipitation frequency curve through log normal distribution concerning this data is plotted in Figure 6. Projected precipitations for 50 and 100 years return periods were computed graphically for their ultimate use in simulations. The hourly distributions of 50 and 100 years return periods are given in Table 2 .

Table 1. Precipitation for Gwadar city (2002-2007).

\begin{tabular}{|c|c|c|c|c|c|c|c|c|c|c|c|c|c|c|c|c|}
\hline \multirow[b]{2}{*}{ Year } & \multicolumn{12}{|c|}{ Monthly Precipitation (mm) } & \multirow{2}{*}{\begin{tabular}{|c} 
Total \\
mm
\end{tabular}} & \multirow{2}{*}{$\begin{array}{c}\text { Mean } \\
\mathrm{mm}\end{array}$} & \multirow{2}{*}{$\begin{array}{l}\operatorname{Max} \\
\mathrm{mm}\end{array}$} & \multirow{2}{*}{$\begin{array}{l}\operatorname{Min} \\
\mathrm{mm}\end{array}$} \\
\hline & JAN & FEB & MAR & APR & MAY & JUN & JUL & AUG & SEP & OCT & NOV & DEC & & & & \\
\hline 2002 & 0 & 0 & 0 & 0 & 0 & - & . & 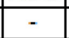 & 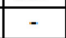 & 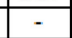 & 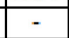 & - & 0 & 0.00 & 0.00 & 0.00 \\
\hline 2003 & 18.5 & 0 & 0 & 0 & 0 & 0 & 12.9 & 7.8 & 0 & 0 & 0 & 9.6 & 48.8 & 4.07 & 18.50 & 0.00 \\
\hline 2004 & 38.3 & 0 & 0 & 0 & 0 & 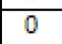 & 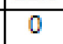 & 0.5 & na & & & 18 & 6.8 & 4.73 & 38.30 & 0.00 \\
\hline 200 & 56 & 17.9 & 15 & 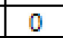 & 1 & 0 & 0.4 & & & & & 0 & 94.3 & 7.86 & 0 & 0.0 \\
\hline 2006 & 5.5 & 8.7 & 24.2 & 0 & 0 & 0 & 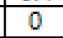 & 0 & & 0 & 0 & 102 & 140.4 & 11.70 & 102.00 & 0.0 \\
\hline 2007 & 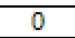 & 5.2 & 33.5 & 0 & 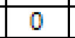 & 51 & & & & & 1 & 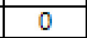 & \begin{tabular}{|l|}
91.7 \\
\end{tabular} & 7.64 & 51.00 & 0.00 \\
\hline Mean & .72 & 5.30 & 12.12 & 0 & 0.17 & 10.20 & 2.66 & 2.66 & 0 & 0 & 0.20 & 25.92 & & & & \\
\hline Max & 56.00 & 17.90 & 33.50 & 0.00 & 1.00 & 51.00 & 12.90 & 7.80 & 0.00 & 0.00 & 1.00 & 102.0 & & & & \\
\hline Min & 0.00 & 0.00 & 0.00 & 0.00 & 0.00 & 0.00 & 0.00 & 0.00 & 0.00 & 0.00 & 0.00 & 0.00 & & & & \\
\hline
\end{tabular}

The frequency curve is indicative of the interesting result about the return period of precipitation amount of $91.7 \mathrm{~mm}$ comprising mainly the precipitation of the 'YEMYIN' cyclone of 2007. The return period corresponding to this amount is about 3 years which has had been naturally validated by 'PEHT' cyclone of June 4, 2010. 


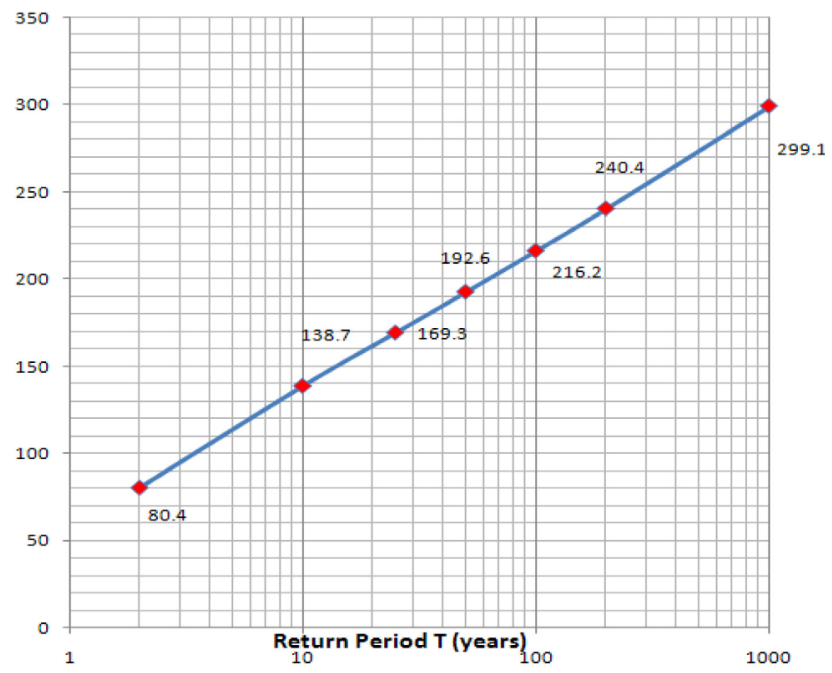

Fig. 6. Precipitation frequency curve (log normal distribution).

Table 2. Distributions of the simulated precipitation.

\begin{tabular}{|c|c|c|c|c|c|c|c|c|c|c|c|}
\hline \multirow{4}{*}{ N I } & \multirow{4}{*}{$\begin{array}{l}\text { Day } \\
\text { of } \\
\text { Jume }\end{array}$} & \multirow{4}{*}{$\begin{array}{l}\text { Hour } \\
\text { of } \\
\text { Pptn. }\end{array}$} & \multicolumn{3}{|c|}{$\begin{array}{l}\text { Precipitation } \\
\text { (Pptn) } \\
\text { Regarding the }\end{array}$} & \multirow[t]{2}{*}{$\mathrm{SN}$} & \multirow{4}{*}{\begin{tabular}{|l} 
Day \\
of \\
Jume
\end{tabular}} & \multirow{4}{*}{$\begin{array}{l}\text { Hour } \\
\text { of } \\
\text { Pptn. }\end{array}$} & \multicolumn{3}{|c|}{$\begin{array}{l}\text { Precipitation } \\
\text { (pptn) } \\
\text { Regarding the }\end{array}$} \\
\hline & & & $\begin{array}{l}\text { Base } \\
\text { Year }\end{array}$ & $\begin{array}{l}\text { Retur } \\
\text { Perio } \\
\text { Of }\end{array}$ & & & & & $\begin{array}{l}\text { Baze } \\
\text { Year }\end{array}$ & $\begin{array}{l}\text { Retur } \\
\text { Perio } \\
\text { Of }\end{array}$ & \\
\hline & & & 2007 & \begin{tabular}{|l}
50 \\
Year5
\end{tabular} & $\begin{array}{l}100 \\
\text { Years }\end{array}$ & & & & 2007 & \begin{tabular}{|l}
50 \\
Years
\end{tabular} & $\begin{array}{l}100 \\
\text { Years }\end{array}$ \\
\hline & & & $\mathrm{mm}$ & $\mathrm{mm}$ & $\mathrm{mm}$ & & & & $\mathrm{mm}$ & $\mathrm{mm}$ & $\mathrm{mm}$ \\
\hline 1 & 25 & $16: 00: 00$ & 1.0 & 2.0 & 2.3 & 16 & 26 & 07:00:00 & 0.0 & 0.0 & 0.0 \\
\hline 2 & 25 & $17: 00: 00$ & 1.1 & 2.3 & 2.6 & 17 & 26 & 08:00:00 & 0.0 & 0.0 & 0.0 \\
\hline 3 & 25 & $18: 00: 00$ & 2.1 & 4.5 & 5.0 & 18 & 26 & 09:00:00 & 0.0 & 0.0 & 0.0 \\
\hline 4 & 25 & $19: 00: 00$ & 0.0 & 0.0 & 0.0 & 19 & 26 & 10:00:00 & 2.6 & 5.5 & 6.2 \\
\hline 5 & 25 & $20: 00: 00$ & 0.0 & 0.0 & 0.0 & 20 & 26 & $11: 00: 00$ & 3.0 & 6.2 & 6.9 \\
\hline 6 & 25 & $21: 00: 00$ & 0.0 & 0.0 & 0.0 & 21 & 26 & $12: 00: 00$ & 5.7 & 12.0 & 13.5 \\
\hline 7 & 25 & $22: 00: 00$ & 0.0 & 0.0 & 0.0 & 22 & 26 & $13: 00: 00$ & 3.0 & \begin{tabular}{|l|}
6.2 \\
\end{tabular} & 6.8 \\
\hline 8 & 25 & $23: 00: 00$ & 0.0 & 0.0 & \begin{tabular}{|l|l}
0.0 \\
\end{tabular} & 23 & 26 & $14: 00: 00$ & 3.3 & 6.9 & \begin{tabular}{|l|l|}
7.8 \\
\end{tabular} \\
\hline 9 & 25 & $24: 00: 00$ & 0.0 & 0.0 & 0.0 & 24 & 26 & $15: 00: 00$ & 6.3 & 13.4 & 15.1 \\
\hline 10 & 26 & $01: 00: 00$ & 0.0 & 0.0 & 0.0 & 25 & 26 & $16: 00: 00$ & 5.6 & 11.5 & 13.3 \\
\hline 11 & 26 & $02: 00: 00$ & 0.0 & 0.0 & 0.0 & 26 & 26 & $17: 00: 00$ & 6.2 & 13.2 & 14.8 \\
\hline 12 & 26 & $03: 00: 00$ & 0.0 & 0.0 & 0.0 & 27 & 26 & $18: 00: 00$ & 12.1 & 25.4 & 28.5 \\
\hline 13 & 26 & $04: 00: 00$ & 0.0 & 0.0 & 0.0 & 28 & 26 & 19:00:00 & 0.5 & 1.1 & 1.2 \\
\hline$\overline{14}$ & 26 & 05:00:00 & 0.0 & 0.0 & 0.0 & 29 & 26 & $20: 00: 00$ & 0.6 & 1.2 & 1.4 \\
\hline 15 & 26 & $06: 00: 00$ & 0.0 & 0.0 & 0.0 & 30 & 26 & $21: 00: 00$ & 1.1 & 2.3 & 2.6 \\
\hline & & & & & & & 2 & 30 & 54.2 & 113.8 & 128.0 \\
\hline
\end{tabular}




\subsection{Model settings for analysis}

Model set up of IISDHM generally includes preparation of input data i.e. spatial data, temporal data, calibration of the model and application of the model. Spatial data includes files related to watershed boundary, river network, DEM, land use and soil map of the catchment. Temporal data consists of hourly rainfall data and evaporation data. In the present study, model set up comprises of $1 \mathrm{~km}$ spatial resolution and 1 hour temporal resolution. Spatial resolution is achieved by processing the downloaded DEM of $990 \mathrm{~m}$ resolution to $1 \mathrm{~km}$. Respective DEM was obtained from official website of USGS and is known as GTOPO DEM $1 \mathrm{~km}$. Land-use map of the respective catchment obtained from official database of FAO was also converted to $1 \mathrm{~km}$ resolution. Respective Manning roughness coefficients were assigned according to the land-use of each Grid. For the channel network, Akara River along with its Chatt tributary was specified. Gauging records of it however could not be available; the boundary conditions were therefore assigned accordingly.

Model calibration in abstract models is always a pivotal phase before the application of the models. Repeated model execution was carried out by tuning the respective parameters, such as manning roughness coefficient, run-off coefficients, until the simulated results were found satisfactorily close to the observed inundation values of the specific past records. The maximum inundation caused by precipitation event of June 2007 was the only record utilized for this purpose. In the absence of an explicit evidence of maximum inundation depth record inside the study watershed, the general maximum inundation depth of 14 feet $(420 \mathrm{~cm})$ quoted David Darg [15] Assistant Director in Operation Blessing International, was utilized in the calibration process. This maximum inundation depth was supposedly referred to a location inside the study watershed. The cell corresponding to maximum inundation was mapped and its reference $\mathrm{x}$ and $\mathrm{y}$ coordinates in Universal Transverse Mercurator (UTM) Projection Coordinate System were found to be $439045.587537 \mathrm{~m}$ and $2818038.18951 \mathrm{~m}$ respectively and hence it was declared as the model calibration reference in the present study. This point lies in the extreme north of the watershed and is shown in the simulation results of the next section.

After calibration, the model is applied against two prospective worst precipitation events of 50 and 100 years return periods. The model application results are produced both graphically and in tabular formats and various inferences are made about the inundation mapping pattern and drainage characteristics of the area under consideration. The results, discussions and conclusions are described in the following section.

\section{Results and discussions}

IISDHM with regards to its overland flow model designates mainly the roughness coefficient and the runoff coefficients as the major calibration parameters. The evaporation parameters in the current scenario of diffusive flow routing environment are not much effective compared with above mention parameters. Flooding event of cyclonic precipitation of $25^{\text {th }}$ and $26^{\text {th }}$ of June 2007 was utilized and the repeated runs were carried out. The appropriate matching of the simulated and observed amounts by adjusting the parameters was achieved. The results of this simulation are shown in Figure 7.

According to simulated results, maximum inundation of $420 \mathrm{~cm}$ occurred outside the Master Plan Area in a cell located at extreme north of the watershed. This depth takes place in the $68^{\text {th }}$ hour of simulation after the start hour of precipitation that was the $16^{\text {th }}$ hour of June 25, 2007. Against the same hour, maximum inundation inside the Master Plan Area is 
$102 \mathrm{~cm}$ at $2 \mathrm{~km}$ southwest of Shahdad area as shown by the city specific enlarged map in Figure 8 .

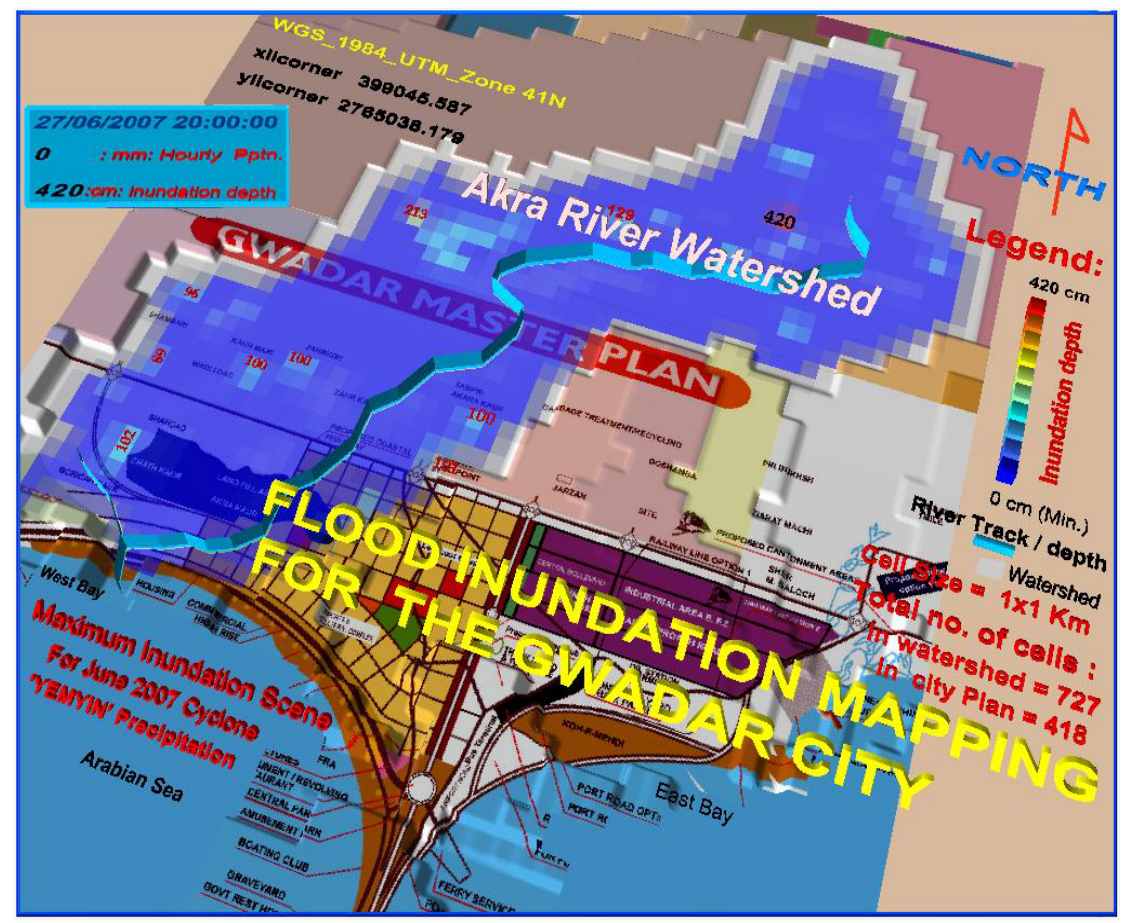

Fig. 7. Simulated view for the cyclonic event of June 2007.

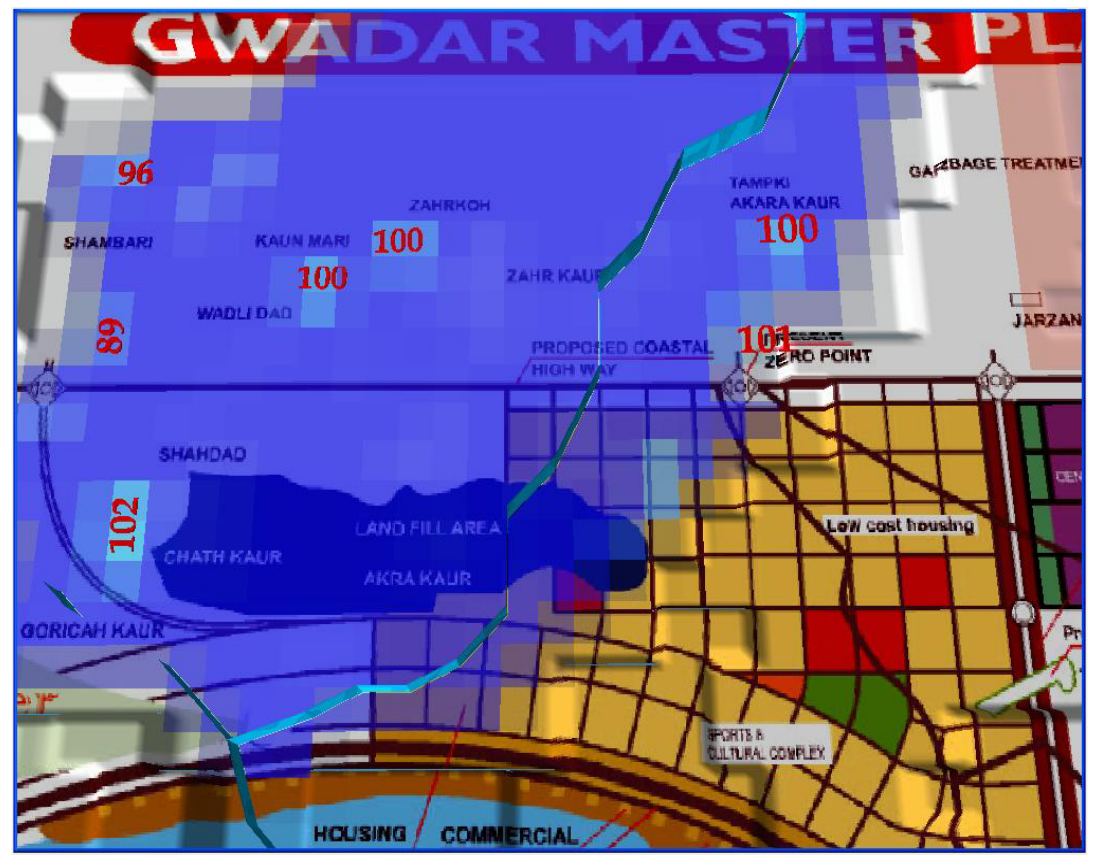

Fig. 8. Enlarged inundation view of June 2007 inundation. 


\subsection{Model application for $\mathbf{5 0}$ years return period}

Model application for the 50 years return period precipitation (Figure 9) shows the maximum inundation of $517 \mathrm{~cm}$ outside the Master Plan Area at the location corresponding to the observed inundation depth of $420 \mathrm{~cm}$ during the event of cyclonic precipitation of June 2007. The simulated maximum inundation inside the Master Plan Area is $180 \mathrm{~cm}$ at the northern part of Shambari area in contrast to the maximum inundation of $101 \mathrm{~cm}$ in the locality of Shahdad area during the cyclonic event of 2007. Besides this contrast of location, there is another temporal discrepancy regarding the occurrence hour of the maximum inundation i.e. in the previous case it is the $68^{\text {th }}$ hour while in this case it is the $43^{\text {rd }}$ hour of precipitation.

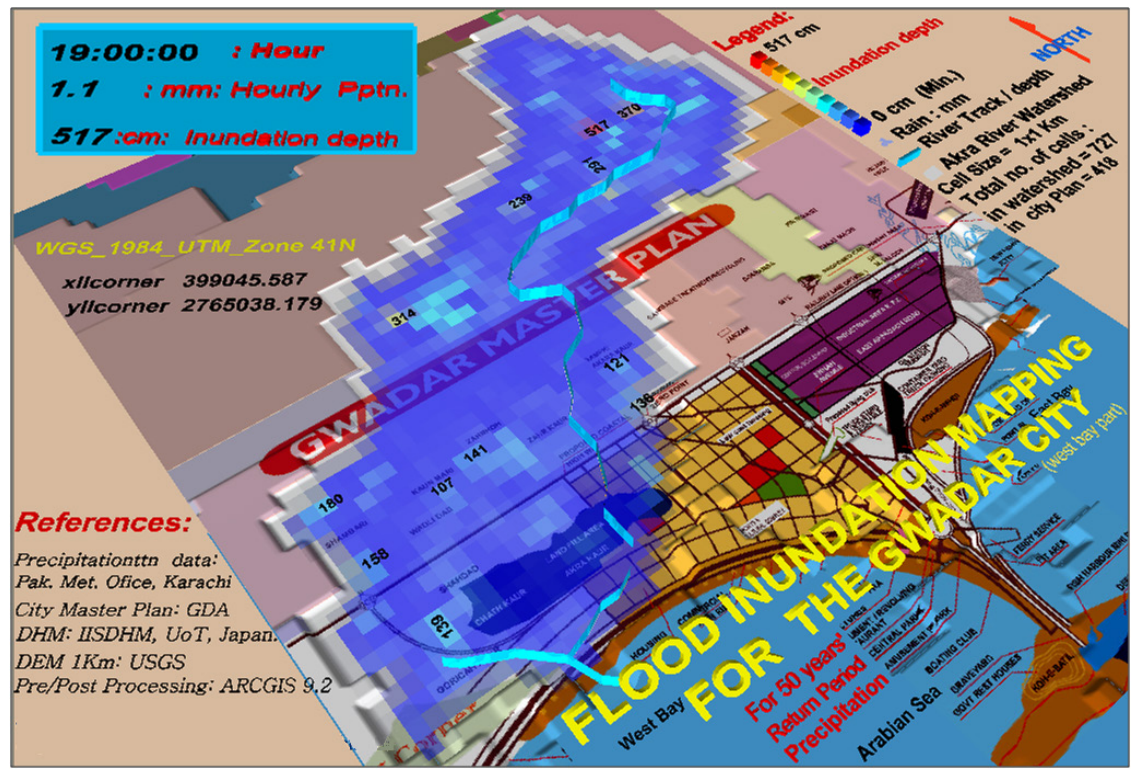

Figure 9. Inundation view for 50 years return period

These spatial and temporal contrasts of inundation are indicative of the varying drainage characteristics of the corresponding watershed under different precipitation intensities that explicitly reflect the temporal scale of the inundation. The other contrasts in inundation depths are due to relatively centrally located cells/clusters of the Master Plan Area. These refer to the locations of Kaun Mari, Zahrkoh and Akara Kaur locations. Corresponding to event of 2007, these depths are $100 \mathrm{~cm}$ for each cell while in the case of inundation for 50 years return period these depths rise to $107 \mathrm{~cm}, 141 \mathrm{~cm}$ and $121 \mathrm{~cm}$, respectively. Figure 10 shows the enlarged view of the Master Plan area. 


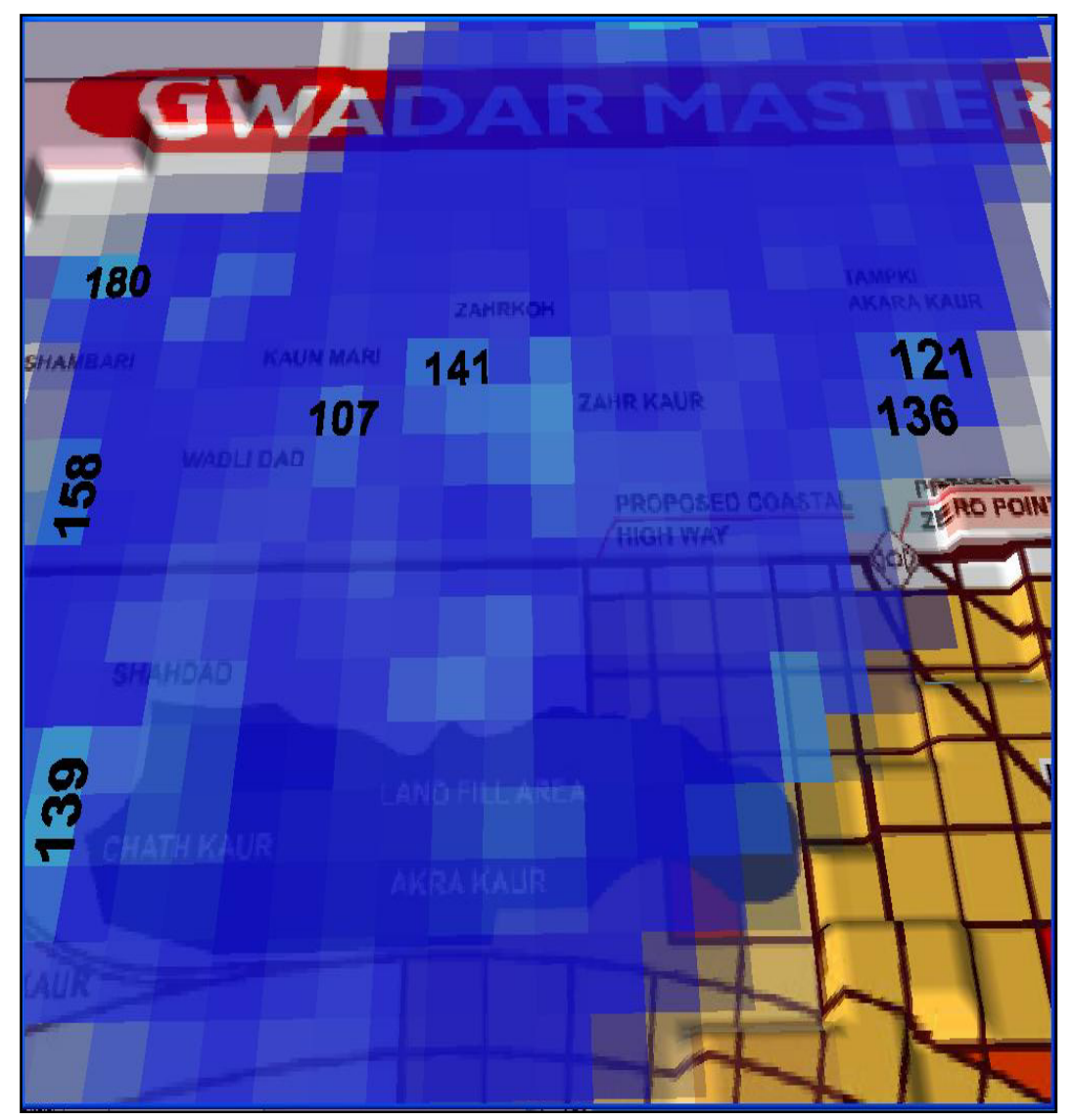

Fig. 10. Enlarged inundation view for 50 years return period.

Another comparison that is noteworthy with regards to inundation is the minimum inundation observed in the context of labeled cells. This minimum simulated inundation depth is observed as $89 \mathrm{~cm}$ in the Shambari locality cell while in the $2^{\text {nd }}$ corresponding case the minimum depth takes place in the Kaun Mari locality cell. This spatial shift regarding the minimum depth in both of the cases may also be considered as another characteristic of the drainage of the watershed.

\subsection{Model application for 100 years return period}

Results from the application of the model for 100 years return period precipitation are shown in the Figure 11. The results are almost similar to those of 50 years return period precipitation. The only temporal difference of one hour earlier (i.e., $42^{\text {nd }}$ hour of simulation) occurrence of maximum inundation depth is observed in this simulation.

The location of maximum inundation like the previous cases is the same. The inundation is exceeded by $4 \mathrm{~cm}$ and $2 \mathrm{~cm}$ outside and inside the Master Plan Area, respectively, in comparison to the case of 50 years return period ( i.e. maximum depth reached outside Master Plan Area in the current scenario is $521 \mathrm{~cm}$ as compared to $517 \mathrm{~cm}$ in case of 50 years return period). Similarly maximum depth arrived inside the Master Plan Area at North of Shambari is $182 \mathrm{~cm}$ as compared to $180 \mathrm{~cm}$ in the case of 50 years return period. 


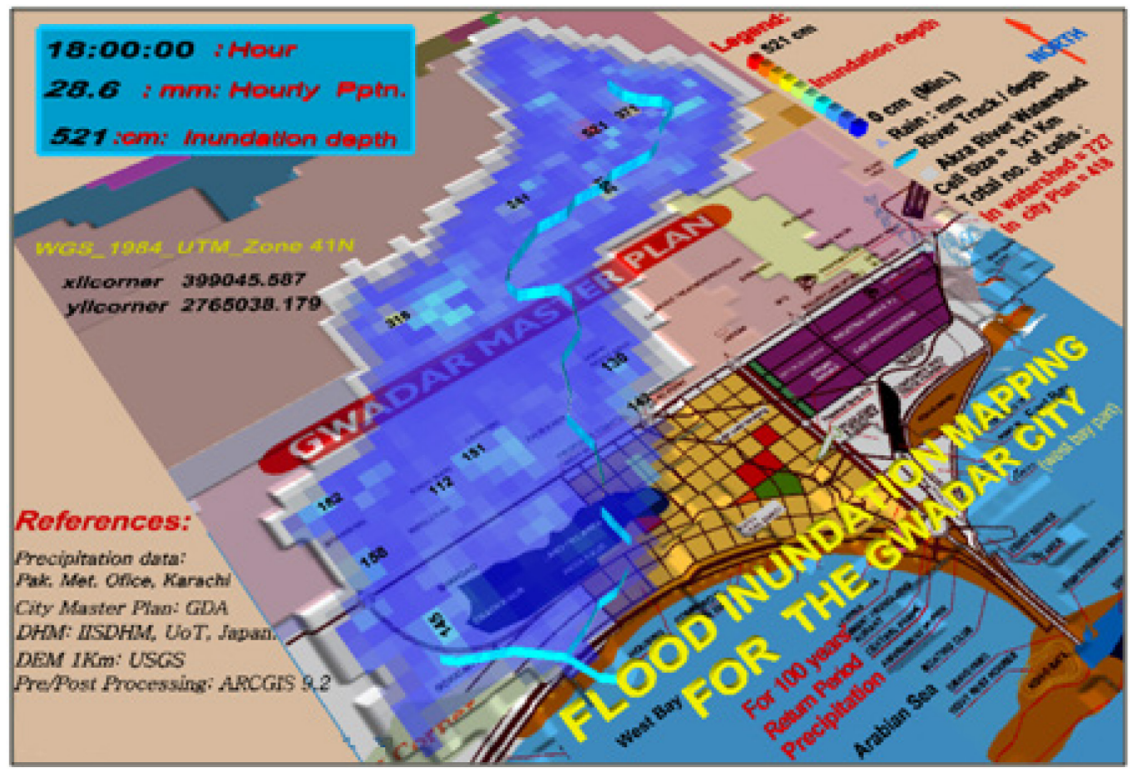

Fig. 11. Inundation view for 100 years return period.

However, the minimum depth in the Master Plan Area is exceeded by $5 \mathrm{~cm}$ as compared to the minimum depth simulated in 50 years return period case. The location of minimum depth is also the same (i.e. KaunMari). Figure 12 shows the enlarged view of inundation in Master Plan Area.

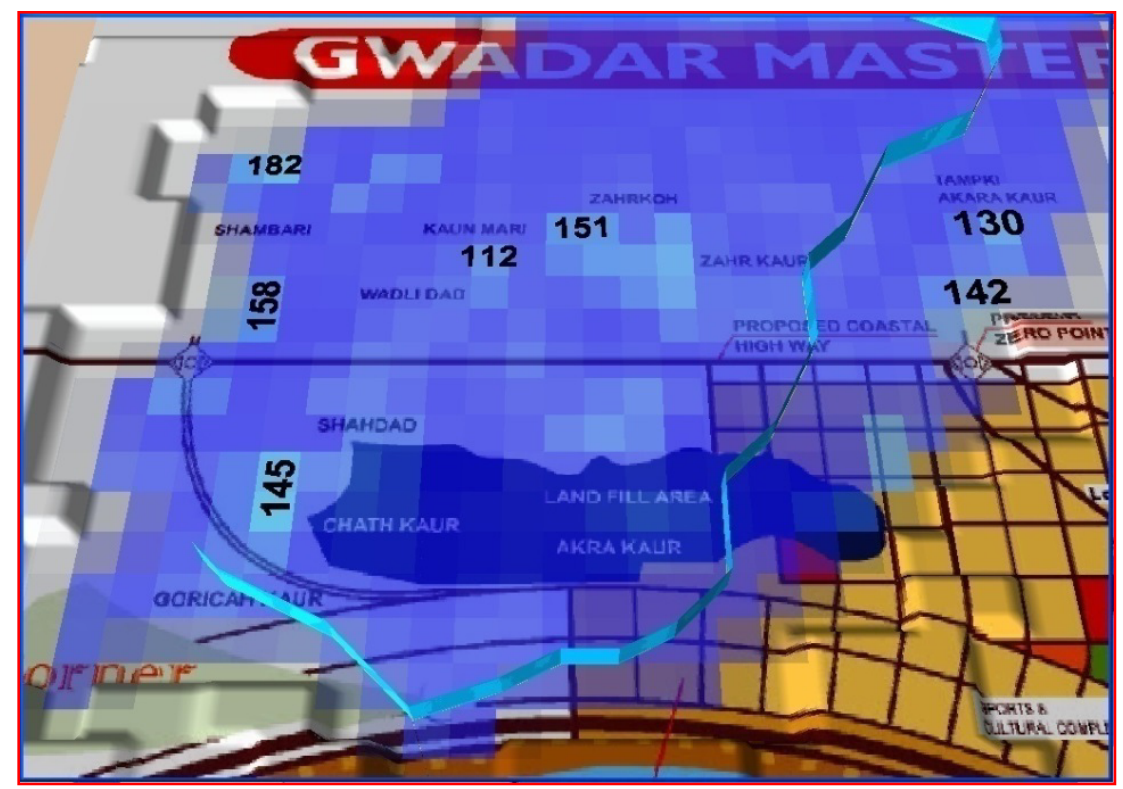

Fig. 12. Enlarged Inundation view for 100 years return period. 
Summarized results of both simulations are given in Table 3 along with location coordinates.

Table 3. Summarized results.

\begin{tabular}{|c|c|c|c|c|c|c|c|c|c|c|}
\hline \multirow{3}{*}{ 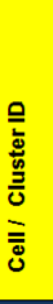 } & \multirow{3}{*}{ 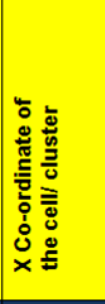 } & \multirow{3}{*}{ 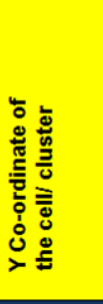 } & \multirow{3}{*}{ 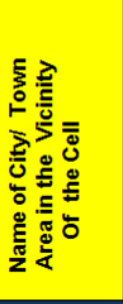 } & \multirow{3}{*}{ 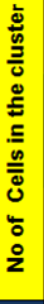 } & \multirow{2}{*}{\multicolumn{2}{|c|}{$\begin{array}{l}\frac{\text { Model Calibration }}{\text { On the basis of }} \\
\text { Inundation from precipitation of } \\
\text { Cyclone 'Yemyin' in Balochistan } \\
\text { On June } 25,26 \& 27,2007\end{array}$}} & \multicolumn{4}{|c|}{$\begin{array}{l}\text { Model Application } \\
\text { For Projected precipitations of }\end{array}$} \\
\hline & & & & & & & \multicolumn{2}{|c|}{$\begin{array}{l}50 \text { Years' } \\
\text { Return Period }\end{array}$} & \multicolumn{2}{|c|}{$\begin{array}{l}100 \text { Years' } \\
\text { Return Period }\end{array}$} \\
\hline & & & & & $\begin{array}{l}\text { Surface } \\
\text { Inundation } \\
\text { Depth. (Max.) }\end{array}$ & $\begin{array}{l}\text { Hour Of } \\
\text { Max. Inund. }\end{array}$ & $\begin{array}{l}\text { Surface } \\
\text { Inundation } \\
\text { Depth (Max.) }\end{array}$ & $\begin{array}{l}\text { Hour } \\
\text { Of } \\
\text { Max. } \\
\text { Inund. }\end{array}$ & $\begin{array}{l}\text { Surface } \\
\text { Inund. } \\
\text { Depth } \\
\text { (Max.) }\end{array}$ & $\begin{array}{l}\text { Hour } \\
\text { Of } \\
\text { Max. } \\
\text { Inund. }\end{array}$ \\
\hline Index & $\mathbf{m}$ & $\mathbf{m}$ & Location & - & $\mathbf{c m}$ & hour & $\mathbf{c m}$ & hour & $\mathrm{cm}$ & hour \\
\hline${ }^{*} \mathrm{R}_{1}$ & 413045.58 & 2795038.1 & Shahdad & 2 & 102 & 68 & 139 & 43 & 145 & 42 \\
\hline$R_{2 s}$ & 412045.58 & 2800038.1 & Shambari & 2 & 89 & 68 & 158 & 43 & 158 & 42 \\
\hline$R_{2 b}$ & 427045.58 & 2800038.1 & ZeroPoint & 1 & 101 & 68 & 136 & 43 & 142 & 42 \\
\hline $\mathrm{R}_{3}$ & 417045.58 & 2801038.1 & KaunMari & 1 & 100 & 68 & 107 & 43 & 112 & 42 \\
\hline$R_{48}$ & 419045.58 & \begin{tabular}{|l|}
2802038.1 \\
\end{tabular} & Zahrkoh & 2 & 100 & 68 & 141 & 43 & 151 & 42 \\
\hline$R_{4 b}$ & 428045.58 & 2802038.1 & Akra-Kaur & 1 & 100 & 68 & 121 & 43 & 130 & 42 \\
\hline$R_{5}$ & 412045.58 & 2804038.1 & $\begin{array}{l}\text { North of } \\
\text { Shambari }\end{array}$ & 1 & 96 & 68 & 180 & 43 & 182 & 42 \\
\hline$R_{6}$ & 439045.58 & 2818038.1 & Outside & 1 & $\begin{array}{l}420=\text { Simulated } \\
\star \star 420=\text { Observed }\end{array}$ & 68 & 517 & 43 & 521 & 42 \\
\hline
\end{tabular}

${ }^{*} R 1, R 2, R 3, R 4$ and $R 5$ are the indices of respective cell-containing rows with subscripts number indicating increase of rows form bottom to top in Watershed, while the subscripts ' $a$ ' and ' $b$ ' represent centre left and centre right cells in the same numbered row, respectively.

** David Darg, July 30, 2007 [15].

***Master Plan Area (MPA)

\section{Conclusions and recommendations}

Based on the results and discussions, the following conclusions can be drawn:

1. Spatial analysis result illustrates that about half of the Master Plan Area of Gwadar city lies in the study watershed, which implies that it is relatively the largest watershed concerning the city Master Plan. Hence, the detailed hydrologic analysis of this watershed is of prime importance in the context of future planning, design or development activity for the Gwadar city.

2. The temporal data analysis through precipitation frequency analysis enabled the estimation of various return periods concerning potential worst precipitations. Based on the frequency curve, the return period of annual precipitation in 2007, comprising mainly that of 'Yemyin' Cyclone, is about 3 years which is really alarming particularly with reference to a coastal city like Gwadar, that is undergoing a mega scale developmental.

3. During the calibration of the model, the simulated results showed a very good agreement with the observed past inundation results.

4. The application of model for 50 and 100 years return period clearly earmarked the potentially hazardous areas both inside and outside the Master Plan Area by depicting the location, extent and depth of inundation. Simulated results, further, depict that the flood inundation depths at the same locations increase by 1.07 to 1.87 times and 1.21 
to 1.89 times, respectively, due to 50 and 100 years return period rainfalls. The concerned authorities are, therefore, recommended to consider this inundation variation spectrum in conjunction with any other prospective similar study of the corresponding area.

5. The comparative statement of results enabled the preparation of the flood vulnerably spectrum of the potentially hazardous areas such as northern locations of Shambari where the maximum inundation of $180 \mathrm{~cm}$ is observed for 50 years return period precipitation. Moreover, outside of Master Plan Area, the potential hazardous location lies at extreme north with maximum inundation depth of $517 \mathrm{~cm}$.

\section{References}

1. M. Haq, M. Akhtar, S. Muhammad, S. Paras, J., Rahmatullah, The Egy. J. RS and Space Sci, Vol. 15, pp. 135-141, (2012).

2. E. Hussain, S. Urala, A. Malik, J. Shana, In Proc. of the ASPRS ann. conf., Milwaukee, WI, USA, 1-5 May 2011, (2011).

3. S. I. Khan, Y. Hong. J.J. Gourley, M. U. Khattak and T. D. Groeve., RS., Vol, 6, pp. 2393-2407, (2014).

4. M. Shakeel, K. Munir, K. Hina, R. Saeed, Q. Arshad., J Earth Sci Clim Change. Vol. 6, pp. 318, (2015).

5. Population Census Organisation (PCO), Population Census -1981, Yearly book, Statistics Division, Ministry of Economic Affairs and Statistics, 69-E, Adeel Plaza, Blue Area, Islamabad, (1981).

6. Directorate of Agriculture (DOA), Balochistan, 1999-2000, Quetta, Pakistan, (2000).

7. U. R. Habib, B. Rabin., Proc. International Symposium, AIT, Bangkok, (2005).

8. R. Jha, S. Herath, and K. Musiake., Proc. of congress of the IAHR, pp 627-632, (1997).

9. R. Jha, S. Herath, and K. Musiake,. A. J. of Hyd. Eng. Vol., 42, (1998).

10. D. Dutta, S. Herath and K. Musiake., Distributed hydrological model for flood inundation simulation, A. J. of Hyd. Eng., Vol. 43, pp 25-30 (1997).

11. D. Dutta, N. Shulian, and K. S. Rajan., Modelling and socio-economic impact analysis of floods in coastal cities under sea-level rising scenarios in Bangkok, Thailand, Proc. International Symposium, AIT, Bangkok, (2005).

12. U. R. Habib, and B. Rabin., Modeling of floods in coastal cities under sea level rising scenarios: a case study of Karachi, Pakistan, International Symposium on Floods in Coastal Cities under Climate Change Conditions, Thailand (2005).

13. H. A. Bakhsh, U. R. Habib, A.S. Shakir, and M. K. Noor., Flood inundation modeling for Malir watershed of Karachi considering future mean sea level rise, Pakistan $J$. of Eng. \& App. Sci, UET, Lahore, Pakistan, Vol. 9, pp. 34-47, (2011).

14. J. George, Theoretical Physics, $2^{\text {nd }}$ ed., Hanfer publishing company, New York, pp. 590-594, (1950).

15. D. David., http://www.alertnet.org/db/blogs/34417/2007/05/27-102352-1.htm, accessed in Jan 2014, (2007). 